A collection of chapters, by many authors, aimed at providing a grounding in established facts and concepts in most aspects of RNA function, devoter to the following subjects: RNA in retrospects (D.S. Letham, P.R. Stewart); Transcription (G.M. Polya); Nuclear RNA (H. Naora); Messenger RNA (J.M. Adams); Transfer RNA and cytokinins (D.S. Letham, R.E.H. Wettenhall); Ribosomal RNA (L. Dalgarno, J. Shine); Translation of messenger RNA (R.E.H. Wettenhall, G.D. Clark-Walker); Mitochondrial RNA (P.R. Stewart); Chloroplast RNA (P.R. Whitfeld); Isolation, purification, and fractionation of RNA (R. Poulzon).

INTEGRATION AND EXCISION OF DNA MOLECULES 28. Colloquium der Gesellschaft für Biologische Chemie

Edited by P.H. Hofschneider and P. Starlinger (München and Köln, FRG). Springer-Verlag, Berlin-Heidelberg 1978. Hard cover, $24.5 \times 17 \mathrm{~cm}$, IX $+134 \mathrm{pp}, 55$ illustrations. Price: DM 48, US $\$ 24.00$.

Proceedings of the 1977 Biochemistry Society's Colloquium, devoted to DNA integration and including a variety of contributions dealing with topics such as gene control in the Imbda repressor, integrations of bacteriophage lambda in DNA recombinant research, integration of bacteriophage $\mathrm{Mu}$. ISelements, tumor viruses and viral integration, viral and chemical carcinogenesis, tumor formation in plants, and related subjects.

\section{THE HLA SYSTEM}

Edited by W.F. Bodmer (Oxford, U.K.). Vol. 34 No. 3 of the British Medical Bulletin, London 1978. $112 \mathrm{pp}$, illustrated. Price: $£ 5$ (outside U.K. $£ 6$ ).

This issue of the British Medical Bulletin provides a general review of the HLA system in all its various aspects. A number of contributions are devoted to the definition and function of the HLA loci, their genetics and biochemistry. However, the general emphasis is on the clinical applications, especially in the field of transplantation and of the associations between HLA system and disease.
BONE DYSPLASIAS OF INFANCY

A Radiological Atlas

By B.J. Cremin and P. Beighton (Cape Town, South Africa). Springer-Verlag, Berlin-Heidelberg 1978. Hard cover, $28 \times 20 \mathrm{~cm}$, XIII $+109 \mathrm{pp}, 124$ illustrations. Subject index. Price: DM 78, US \$ 39.00.

A combination of systematic assessment of the radiological evidence and the genetic characteristics of the bone dysplasias of infancy, such as achondrogenesis, thanatophoric dysplasia, asphyxiating thoracic dysplasia, chondroectodermal dysplasia, lethal short rib-polydactyly syndromes, chondrodysplasia punctata, camptomelic dysplasia achondroplasia, diastrophic dysplasia, metatropic dysplasia, spondyloepiphyseal dysplasia congenita, mesomelic dysplasia, Larsen syndrome, cleido-cranial dysplasia, osteogenesis imperfecta congenita, hypophosphatasia, osteoporosis, and other sclerosing bone dysplasias.

The atlas is completed by a glossary of useful terms, some comments on terminology, and general notes on the clinical and genetic evaluation of the neonate with skeletal dysplasia, as well as on radiographic techniques.

\section{HAEMATOLOGIE}

Physiologie, Pathologie, Klinik

Hematology - Physiology, Pathology, Clinic. Edited by E. Kleihauer (UIm, FRG), in cooperation with E. Kohne and D. Niethammer; contributions by $E$. Kleihauer, E. Kohne, D. Niethammer, R. Haas, H. Rasche, A. Olischläger, U. Bienzale. SpringerVerlag, Berlin-Heidelberg 1978. Hard cover, $24.5 \times$ $17.5 \mathrm{~cm}$, XIV $+608 \mathrm{pp}, 101$ illustrations. Subject index. Price: DM 98, US $\$ 49.00$.

A beautifully designed and beautifully produced, authoritative handbook, consisting of eleven wellorganized chapters, respectively devoted to: the bone marrow, the erythrocyte, the granulocyte, the monocyte, the lymphatic system, the complement, leukemias, malignant lymphomas, hemostasis, hematology of newborn, and hematologic troubles and organic diseases. A very detailed index completes this precious volume.

\section{DAS EGOISTISCHE GEN}

THE SELFISH GENE. By R. Dawkins (Oxford, U.K.) Springer-Verlag, Berlin-Heidelberg 1978. Soft cover, $23 \times 15 \mathrm{~cm}$, XII +246 pp. Subject index. Price not indicated. 